\title{
The Use of Electronic Educational Resources of the University as a Means of Increasing the Educational Motivation of Students
}

\author{
https://doi.org/10.3991/ijet.v16i01.16799 \\ Irina Talysheva $\left.{ }^{(}\right)$, Khene Pegova, Liliya Khaliullina \\ Kazan Federal University, Elabuga, Russian Federation \\ IATalysheva@kpfu.ru
}

\begin{abstract}
The relevance of using electronic educational resources as a means of developing educational motivation is determined by a detailed study of issues related to the use of this educational technology in practice in the modern educational process. Electronic resources are a technology-based media that can be used to increase the educational motivation of students. One of the most famous and widespread distance learning management systems that is used in EI KFU is LMS Moodle. Its application can motivate students. The aim of our research work was to study the relationship of educational motivation of students and their relationship to the use of electronic educational resources for the subsequent improvement of the quality of education at a university. Based on a survey and questionnaire of 100 respondents, the authors analyzed topical issues of using electronic educational resources and types of educational motivation of students with a pedagogical profile. The authors studied the impact of electronic educational resources on the effectiveness of the educational process and increasing student motivation. Features of the organization of this process are considered on the example of the Elabuga Institute of Kazan Federal University. The study made it possible to identify factors that influence the motivation of students to use electronic educational resources, which makes the scientific significance of this study. The identified factors allowed the authors to develop conditions for increasing students' motivation, which indicates the practical contribution of this study and can be used by university teachers in order to improve and develop the educational process in modern educational institutions.
\end{abstract}

Keywords—Digital technologies, distance learning, electronic educational resource, Moodle platform

\section{$1 \quad$ Introduction}

The development of modern society, the processes of globalization and informatization have led to the fact that personnel specialists should now pay attention to such human activity, which includes the following components: the ability to learn and adapt to new environmental and social challenges. All these data are aimed at the 
development of the educational process, which should be formed for students for their active and productive life in society [9].

This trend in the development of the education system implies the existence of a number of requirements for the personality of teachers, which should be able to recruit teachers, as well as bear in mind the need to change the content of the training of students of a pedagogical university. Teachers of the new generation are engaged in digital literacy, which makes it possible to use all the necessary knowledge and skills [7], [12], [11].

These trends lead to the search for innovative ways to organize student learning using digital components (digital competencies, digital consumption, digital security). The use of information technology in the framework of teaching and research areas, with the exception of issues related to the independent work of students, where electronic educational resources play a large role.

Technologically advanced training has gradually become an area for research and the application of information and communication technologies in teaching and learning. In particular, for teaching, the numerous standard compatible repositories of teaching materials available on the Internet and open repositories of educational resources provide tremendous support for teachers when they need to develop a course that can also use existing teaching materials [4]. Technological advances have a direct impact on the world of education where e-learning-based teaching becomes an option that can support and teach students in developing materials and abilities in the field of technology [6;17-20].

In solving this issue, an increasingly important role is given to e-learning and distance educational technologies, much attention is paid to improving the quality of information and educational resources being developed. The same point of view is shared by M. Kalogiannakis and S. Papadakis [14]. According to them the use of learning management systems has grown considerably in universities around the world.

Moreover, a lot of scientists think that e-learning technologies are increasing the value of the educational process due to the fact that they level up students' motivation to learning in general. K. Bovermann, J. Weidlich, and T. Bastiaens [15] point out that motivation is one of the key determinants for successful learning. Supporting this idea, D.N. Mavardi [16] tells that the success of the learning and teaching activities can be seen from all factors related to educators and students. The attitude of students while carrying out learning can indicate whether students are interested in the lessons being carried out or even vice versa, that's why it extremely important to know students' attitude [21;22].

One of the most famous and widespread distance learning management systems at EI KFU is LMS Moodle (Modular Object-Oriented Dynamic Learning Environment).

LMS Moodle is a successful and constantly evolving project. LMS Moodle is a software package for creating distance learning courses and websites. Distance learning on the LMS Moodle platform includes the main forms of learning online and offline. Teaching and learning in the Moodle eLearning environment as a blended learning environment is very useful for increasing learning efficiency and also helps to increase the motivation to learning process [8]. 
The widespread use of Moodle is because of its versatility and various features that support almost every aspect to attain successful teaching-learning endeavors. Currently, on the basis of the LMS Moodle system, distance learning has been organized in many of the largest universities in the world from 193 countries [10], [4], [1]. The program has been translated into more than 75 languages, including Russian. On the Internet there are more than 250 Russian-language sites of educational institutions working on LMS Moodle software.

This indicates the prevalence of the use of LMS Moodle in education. However, there is a contradiction, which is explained by the fact that, despite the massiveness of its use, many institutions in different parts of the world had spent a considerable amount of resources in the trial-and-error before reaping the great benefits of Moodle [3].

Moreover, according to the research conducted by S. Papadakis, M. Kalogiannakis, E. Sifaki, and N. Vidakis [13] it is important to take into account the students' point of view since they are the main users of the electronic educational resources and can cooperate in implementing and improving an e-course as a very important stakeholder in the e-learning process.

In this regard, a number of questions arise: what are the problems of using LMS Moodle? What are the possibilities of LMS Moodle as a means of increasing student learning motivation? Is it advisable to use LMS Moodle as a means of increasing student learning motivation?

The formulation of these questions and the identification of the contradiction allowed us to formulate the purpose of the research: to study the relationship between educational motivation of students and their attitude to the use of electronic educational resources for the subsequent improvement of the quality of education at the university.

Research objectives:

- Revealing the relevance of using LMS Moodle in the educational process

- Development of tools for determining the importance and place of electronic educational resources in the educational activities of students

- Conducting a survey

- Processing of the received data

- Formulation of conclusions that allow to identify the significance of this research, substantiation of the practical significance of the research

\section{Materials and Methods}

The purpose of the study is concretized by a set of interrelated research questions that determine, in turn, the methods used:

1. Is there a connection between the use of electronic educational resources in the educational process and the educational motivation of students?

2. What is the nature of the relationship between the use of electronic educational resources and the educational motivation of students? 
3. What is the reason for the other: the active use of electronic educational resources increases the educational motivation of students, or vice versa?

To achieve the set goals, objectives and answer these questions, the following research logic was built and an analytical study was carried out, suggesting:

1. First of all, the urgency of using electronic educational resources in the modern world the ability of electronic resources to facilitate the learning process of students, as a result of increasing their motivation for learning were substantiated. For this, the collection of theoretical data was carried out, which formed the necessary basis for the use of such basic methods of theoretical research as the analysis of psychological and pedagogical literature on the research topic.

To answer these questions, an analytical study was carried out, suggesting:

1. Analysis of statistics on the use of electronic educational resources by various teachers and grades received by students during the final tests on the subject (first stage).

2. Conducting a pilot study based on focused interviews with teachers and students (second stage).

3. Formative experiment. The results of the interview allow us to develop a questionnaire to summarize the formative experiment (the third stage) to test the hypothesis about the positive impact of electronic educational resources on the educational motivation of students. In the case of confirmation of the indicated hypothesis, we get answers to all formulated research questions.

Prior to the study, the logic of determining how and what data should be collected was theoretically built and justified in order to most adequately and fully solve the tasks posed in the study and answer research questions.

The general scientific research methodology is represented by directions, concepts and systems of scientific knowledge, which, due to their universality, are used as means of research in various branches of science.

A study related to the functioning and development of the educational process and educational institutions is of an applied complex psychological and pedagogical character.

The authors of the work also used a set of additional methods of theoretical research, allowing studying the content of the research problem, to formulate the goal, the subject of research, as a theoretical generalization and systematization of theoretical and experimental data. The methods of empirical research were also used: Observation; questioning; interview.

In the process of the study, the authors ensured the inclusion of students in the electronic educational environment, by working on the platform LMS Moodle, in accordance with the content of the research problem, purpose, subject of study and formulated tasks. The research methodology developed by the author is based on a theoretical analysis of scientific works and his own practical experience in the use of electronic educational resources in the educational process of higher education. The authors of the study suggested that to increase educational motivation students use 
didactically built electronic educated resources when doing homework. Students had to answer a number of questions. Students had to answer a number of questions. The study was conducted from October 2017 to February 2020. The following variables were analyzed:

a) The use of electronic educational resources in the preparation of homework

b) Educational motivation of students of a pedagogical university

The obtained variables made it possible to conduct a comparative analysis of indicators: Students' attitudes to the use of electronic resources and educational motivation.

\subsection{Limitations of the research}

While conducting the study the following limitations were observed:

1. The first group of limitations is connected with the sample. In connection with the fact that a specific feature of the teaching profession in Russia is the fact that mostly female teachers work as teachers, respectively, girls are more likely to study in higher educational institutions than boys. In our opinion, the results of the study may be different if male students answered. This is due to the fact that, in principle, it is much easier for male students to use electronic means than for female.

2. The second group of limitations refers to the timing of the study. The research was conducted once a year in December. The survey was carried out in fresh footsteps, since the students had studied how to use electronic educational resources in September. If the study was carried out later, after some time, the results might also be different. This is due to the fact that over the past time, students could perform reflection, which would affect their attitude.

3. The $3 \mathrm{~d}$ group of limitations is connected with the general student's attitude to the educational process. This means that the study sample included not only students who have a negative attitude to electronic educational resources, but even among them there are those who have a negative attitude towards learning in general, which can also affect the research results.

\subsection{Participants}

The total sample of respondents is 100 people aged 19-21, among them 64 people are citizens of the Russian Federation and 36 people are foreign students (mainly from Turkmenistan). It should be noted that since the study involved students of the pedagogical field of study, students who plan to connect their lives with the teaching profession, the majority of the respondents were women -73 people. The study participants were students of the Faculty of Physics and Mathematics (54 people), who primarily use electronic educational resources in the educational process, as well as students of the Faculty of Psychology and Pedagogy (46 people) - this sample uses mainly traditional forms of independent work in the educational process). Students had various experience working with electronic educational resources: from its com- 
plete absence (46 people) to training experience on the LMS Moodle platform from 1 to 3 years.

\subsection{Instrumentations}

The main tools of our research were questionnaires and surveys. The study was carried out in 2 stages:

As part of the first stage, we compiled a questionnaire, which includes 6 closedended questions, to study students' attitudes toward electronic educational resources. For convenience, we used a scale from 1 to 10 . Surveys allowed us to determine how important electronic educational resources are for preparing for classes, how often modern students work with them, what information environment attracts them more, and how positively they perceive a new form of organization of independent work.

At the second stage, educational motivation was diagnosed using the methodology for student learning motivation diagnostics developed by A.A. Rean and V.A. Yakunin in the modification of N.Ts. Badmaeva. In the process of modifying N.Ts. Badmaev added to the 16 statements of the questionnaire developed by A. A. Rean and V. A. Yakunin statements characterizing the motives of the teachings identified by V. G. Leontiev, as well as statements characterizing the motives of the teachings she received as a result of a survey of students and schoolchildren.

To diagnose educational motivation, a questionnaire consisting of 34 declared was used. Students had to agree or refute these statements within 5-point scales related to communicative, professional, educational, cognitive, social motives, motives of creative self-realization, motives of avoiding failure and prestige. Students evaluated the given motives of educational activity by the 5-point system according to the degree of importance for them: 1 point corresponded to the minimum significance of the motive, 5 points - the maximum.

\subsection{Data collection}

A survey to identify students' attitudes to electronic educational resources and to diagnose their impact on educational motivation when performing students' independent work was conducted at the Elabuga Institute of Kazan Federal University.

Data collection for the study was carried out in the period from 2017 to 2020, once a year in November, students were asked to go through dedicated work in electronic educational resources, and once a year in December, students were diagnosed with educational motivation. The motivation of the participants for the study was in the form of a conversation in a relaxed atmosphere. Respondents responded adequately, responsibly and willingly passed the survey. In the first year (2017), 20 respondents took part in the study: 10 students of the Faculty of Physics and Mathematics and 10 students of the Faculty of Psychology and Pedagogy, in the second year (2018) the number of students was 22 people, including 12 students of the Faculty of Physics and Mathematics and 10 students of the Faculty of Psychology and Pedagogy, in the third year (2019), the total number of 24 students, of which 14 are students of the Faculty of Physics and Mathematics and 10 students of the Faculty of Psychology and Peda- 
gogy, in the fourth year the total number of respondents was 34 students, of which 18 were students of Physics and Mathematics faculty and 16 students of the faculty of psychology and pedagogy. The total number of respondents for 4 years was 54 students of the Faculty of Physics and Mathematics and 46 students of the Faculty of Psychology and Pedagogy.

Based on this technique, we determined the current state of independent work of university students and the main difficulties of its organization with the traditional approach, the attitude of modern students to it, their understanding of its essence, the most frequently used forms and means, including the degree of use of information and communication tools technology.

The educational motivation of students was studied by means of a diagnostic technique for educational motivation of students developed by the authors A.A. Rean and V.A. Yakunin in the modification of N.Ts. Badmaeva, which included the following statements that students needed to rank at 5-point school.

During the processing of the obtained data, the main stages of work were:

1. Determining the values of the use of electronic educational resources in the process of students' independent work;

2. Analysis of the frequency of students' access to electronic educational resources;

3. Identifying the attractiveness for students of the use of electronic educational resources;

4. Analysis of factors hindering the organization, providing independent work on the electronic educational resource;

5. The identification of the prevailing motives of educational activity.

To test students' attitudes towards electronic educational resources, students were asked to rate the following questions on a 10-point scale:

1. Evaluate the importance of e-learning resources in preparing for classes?

2. How effectively do you find the necessary information in a search engine?

3. Is it convenient for you to work with electronic educational resources?

4. Rate the information content of the electronic educational resource?

5. Estimate the time spent on independent work in the framework of electronic educational resources?

6. Can you learn more successfully through e-learning resources?

Within each main section, three levels of subheadings are available, and the titles must be bold, bold, and italic, italic, respectively. Font size: 10.

In parallel, students were offered sheets of anonymous answers to the questions of the questionnaire, identical in meaning to the above, but suggesting detailed answers in free form, to which they had the opportunity, within half an hour, to express their attitude to working with electronic educational resources and evaluate their capabilities and abilities when doing independent work.

Based on this technique, we determined the current state of independent work of university students and the main difficulties of its organization with the traditional approach, the attitude of modern students to it, their understanding of its essence, the most frequently used forms and means, including the degree of use of information and communication tools technology. 
The educational motivation of students was studied through the diagnosis of educational motivation of students on the basis of a standardized methodology developed by the authors A.A. Rean and V.A. Yakunin in the modification of N.Ts. Badmaeva, which included the following statements that students needed to be ranked on a 5point scale:

1. I study because I like the chosen profession.

2. To ensure the success of future professional activities.

3. I want to become a specialist.

4. To provide answers to pressing questions related to the field of future professional activity.

5. I want to make full use of my inclinations, abilities and inclinations to the chosen profession.

6. To keep up with friends.

7. To work with people, you need to have deep and comprehensive knowledge.

8. Because I want to be among the best students.

9. Because I want our study group to become the best at the institute.

10. To make acquaintances and chat with interesting people.

11. Because the knowledge gained will allow me to achieve everything necessary.

12. It is necessary to graduate from the institute so that acquaintances do not change their opinion of me as a capable, promising person.

13. To avoid condemnation and punishment for poor study.

14. I want to be a respected student.

15. I do not want to lag behind fellow students, I do not want to be among the laggards.

16. Because the level of my material depends on success in school security in the future.

17. Successfully study, take exams for " 4 " and " 5 ".

18. Just like to study.

19. Once in college, forced to study in order to graduate.

20 . To be constantly ready for the next classes.

21. Successfully continue training in subsequent courses to give answers to specific training questions.

22. To acquire deep and lasting knowledge.

23. Because in the future I think to engage in scientific activities on specialty.

24. Any knowledge will be useful in the future profession.

25 . Because I want to bring more benefits to society.

26. Become a highly qualified specialist.

27. To learn new things, engage in creative activities.

28. To give answers to the problems of development of society, life of people.

29. To be in good standing with teachers.

30. Seek the approval of parents and others.

31. I study for the sake of performance of a duty to parents, school.

32. Because knowledge gives me confidence.

33. Because of my academic success my future career depends position.

34. I want to get a diploma with good grades in order to have advantage over others.

The results were analyzed and interpreted. 


\subsection{Data analysis techniques}

In the current study, the authors applied a qualitative analysis using a comparative method, since this analysis allows us to determine the attitude of students to electronic educational resources and how this affects their educational motivation, comparing the answers to the survey and the survey results of students of physical, mathematical and psychological-pedagogical faculties in the first, second, third and fourth years of the study. The results were analyzed and interpreted, at this stage the statistical processing of the empirical results of our study was carried out, which was carried out using the t-student criterion. This criterion made it possible to reliably determine whether there are differences in educational motivation among students of the Faculty of Psychology and Pedagogy and the Faculty of Physics and Mathematics.

\section{Results and Discussion}

The following results were obtained in the first phase of the study, devoted to the study of students' attitudes towards electronic educational resources:

Table 1. Subjects' answers to the question "What is the importance of electronic educational resources for preparing for classes?"

\begin{tabular}{|l|c|c|}
\hline \multicolumn{1}{|c|}{ Answer options } & \multicolumn{1}{|c|}{$\begin{array}{c}\text { Faculty of Physics and } \\
\text { Mathematics } \\
\text { (54 students) }\end{array}$} & $\begin{array}{c}\text { Faculty of Psychology and } \\
\text { Pedagogy } \\
\text { (46 students) }\end{array}$ \\
\hline Work in the library & $7.4 \%$ & $28.3 \%$ \\
\hline Work in the electronic library & $14.8 \%$ & $23.9 \%$ \\
\hline Use of electronic educational resource & $42.6 \%$ & $10.9 \%$ \\
\hline Other Internet sources & $35.2 \%$ & $36.9 \%$ \\
\hline
\end{tabular}

Analysis of the questionnaire of students of the Faculty of Physics and Mathematics showed that for them the most important thing in preparing for classes is working with electronic educational resources and on the Internet. Unfortunately, students of the Faculty of Physics and Mathematics prefer not to use the resources of the reading room and the subscription of the institute. An analysis of a survey of students of the faculty of psychology and pedagogy showed that for them the most important thing in preparing for classes is work in the library and in the electronic library, but the Internet is the main source of information for homework.

Table 2. Subjects' answers to the question "How do you find the necessary information in the search engine?"

\begin{tabular}{|l|c|c|}
\hline \multicolumn{1}{|c|}{ Answer options } & $\begin{array}{c}\text { Faculty of Physics and } \\
\text { Mathematics } \\
\text { (54 students) }\end{array}$ & $\begin{array}{c}\text { Faculty of Psychology and } \\
\text { Pedagogy } \\
\text { (46 students) }\end{array}$ \\
\hline I find the first link & $59.2 \%$ & $30.5 \%$ \\
\hline I look through 3-5 sources & $27.9 \%$ & $54.3 \%$ \\
\hline I put a lot of effort into finding information & $12.9 \%$ & $15.2 \%$ \\
\hline
\end{tabular}


After analyzing the answers of students of the faculty of psychology and pedagogy to the second question of the questionnaire "How do you find the necessary information in the search engine?", We came to the conclusion that students are not ready to make a lot of efforts to find information, usually they are limited to viewing several pages of the search query. Students of the Faculty of Physics and Mathematics showed slightly different results, namely they answered that they use the first link that satisfies their request.

Table 3. Subjects' answers to the question "Rate on a scale of 1 to 10 the convenience of working in an electronic educational resource"?

\begin{tabular}{|l|c|c|}
\hline Answer options & $\begin{array}{c}\text { Faculty of Physics and } \\
\text { Mathematics } \\
\text { (54 students) }\end{array}$ & $\begin{array}{c}\text { Faculty of Psychology and } \\
\text { Pedagogy } \\
\text { (46 students) }\end{array}$ \\
\hline from 1 to 3 & $7.4 \%$ & $13 \%$ \\
\hline from 4 to 6 & $20.4 \%$ & $69.6 \%$ \\
\hline from 7 to 10 & $72.2 \%$ & $17.4 \%$ \\
\hline
\end{tabular}

Respondents from the faculty of psychology and pedagogy rated the convenience of working on electronic educational resources quite positively. It should be noted that students of the Faculty of Physics and Mathematics also highly rated electronic educational resources.

Table 4. Subjects' answers to the question "Rate on a scale from 1 to 10 the degree of informational content of an electronic educational resource"

\begin{tabular}{|l|c|c|}
\hline \multicolumn{1}{|c|}{ Answer options } & $\begin{array}{c}\text { Faculty of Physics and } \\
\text { Mathematics } \\
\text { (54 students) }\end{array}$ & $\begin{array}{c}\text { Faculty of Psychology and } \\
\text { Pedagogy } \\
\text { (46 students) }\end{array}$ \\
\hline from 1 to 3 & $5.6 \%$ & $21.7 \%$ \\
\hline from 4 to 6 & $35.2 \%$ & $32.6 \%$ \\
\hline from 7 to 10 & $59.2 \%$ & $45.7 \%$ \\
\hline
\end{tabular}

Respondents rated the degree of informativeness of electronic educational resources for independent work on a scale of 1 to 10 points. Most students of the faculty of psychology and pedagogy believe that electronic educational resources contain all the necessary information for studying the educational course. The results of a survey among students of the Faculty of Physics and Mathematics showed that most are satisfied with the informativeness of electronic educational resources. 
Table 5. Subjects' answers to the question "How much time do you spend on independent work in the framework of electronic educational resources?"

\begin{tabular}{|l|c|c|}
\hline \multicolumn{1}{|c|}{ Answer options } & $\begin{array}{c}\text { Faculty of Physics and Mathematics } \\
\text { (54 students) }\end{array}$ & $\begin{array}{c}\text { Faculty of Psychology and Pedagogy } \\
\text { (46 students) }\end{array}$ \\
\hline 1-2 hours & $12.9 \%$ & $50 \%$ \\
\hline 3-4 hours & $50.1 \%$ & $50 \%$ \\
\hline 5-6 hours & $25.9 \%$ & 0 \\
\hline More than 6 hours & $11.1 \%$ & 0 \\
\hline
\end{tabular}

According to the results of the responses, it can be noted that students of the Faculty of Physics and Mathematics spend on average more time working independently in the framework of the electronic course than students of the Faculty of Psychology and Pedagogy.

Table 6. Subjects" answers to the question "What prevents you from learning more successfully in the framework of the electronic educational resource"

\begin{tabular}{|l|c|c|}
\hline \multicolumn{1}{|c|}{ Answer options } & $\begin{array}{c}\text { Faculty of Physics and Mathematics } \\
\text { (54 students) }\end{array}$ & $\begin{array}{c}\text { Faculty of Psychology and } \\
\text { Pedagogy } \\
\text { (46 students) }\end{array}$ \\
\hline No or low motivation & $20.4 \%$ & $43.5 \%$ \\
\hline Lack of electronic skills & $25.9 \%$ & $47.9 \%$ \\
\hline Laziness, no desire to learn & $53.7 \%$ & $4.3 \%$ \\
\hline Technical problems & 0 & $4.3 \%$ \\
\hline
\end{tabular}

From the students' answers to this question, it can be concluded that the main obstacle to the successful preparation of students of the faculty of psychology and pedagogy is the lack of skills in working with electronic educational resources. The success of training with students of the Faculty of Physics is directly related to the low level of educational motivation.

As part of the second phase of the study, dedicated to the diagnosis of educational motivation of students, the following results were obtained.

Table 7. Diagnostic results of student educational motivation

\begin{tabular}{|l|c|c|}
\hline \multicolumn{1}{|c|}{ Type of motive } & $\begin{array}{c}\text { Faculty of Physics and Mathematics } \\
\text { (54 students) }\end{array}$ & $\begin{array}{c}\text { Faculty of Psychology and } \\
\text { Pedagogy } \\
\text { (46 students) }\end{array}$ \\
\hline Communicative motives & $3.7 \%$ & $30.5 \%$ \\
\hline Motives for avoiding & $22.2 \%$ & $13 \%$ \\
\hline Motives of prestige & $14.8 \%$ & $4.4 \%$ \\
\hline Professional motives & $18.5 \%$ & $8.7 \%$ \\
\hline Motives of creative self-realization & $18.5 \%$ & $13 \%$ \\
\hline Educational motives & $14.8 \%$ & $4.3 \%$ \\
\hline Social motives & $7.5 \%$ & $26.1 \%$ \\
\hline
\end{tabular}

Diagnostic data showed that students of the Faculty of Physics and Mathematics are dominated by educational, cognitive, professional, creative motives, motives of 
avoidance and prestige compared with the faculty of psychology and pedagogy, which, in turn, is dominated by communicative and social motives, which can easily be explained professional orientation of this faculty.

Thus, based on the survey, we can make the assumption that students of the Faculty of Physics and Mathematics, working on the electronic educational platform from the first year of study, are more motivated to do independent work using electronic educational resources. It does not cause them technical problems, they use various gadgets, there is no internal resistance when completing tasks, the time they work with electronic educational resources is distributed more rationally by them. A slightly less positive picture of the attitude to electronic educational resources among students of the faculty of psychology and pedagogy who perceive this form of independent work as an additional burden to traditional homework.

The prevailing group of motives among students of the Faculty of Physics and Mathematics, in our opinion, is due to the fact that the students of this faculty from the first year are focused on independent work, which is organized mainly through electronic educational resources. The predominance of independent work forms in them a creative attitude towards obtaining information, an awareness of the need for this information for their future activities, and even an increased motive for avoiding failure forces students to find alternative ways to solve problems. However, the predominance of virtual communication eliminates the communication skills that are necessary for personal implementation in any profession.

Communicative motives, avoidance motives, creative motives, educational and cognitive motives, as well as social motives fell into the zone of significance, which indicates the need for the use of the LMS Moodle electronic educational platform in a wider format. Also, based on the results obtained, we can conclude that the implementation of e-learning through educational sites is effective. However, do not idealize e-learning, as communicative and social motives of students of the faculty of psychology and pedagogy were higher. These are the motives that should be present in order to form the competencies necessary for each professional working in society.

Professional motives fell into the trend zone. Obviously, the professional orientation of students of both faculties is a significant incentive to study at a university. Students already see themselves in a future profession and focus on those competencies that they will need when mastering it.

Motives of prestige are expressed in the desire to realize their social role, to take part in socially significant activities. That is why the results of statistical processing of data by the t-criterion of student between students of the faculty of psychology and pedagogy and students of the physics and mathematics faculty showed no difference. This suggests that modern students seek self-realization through professional activities.

\section{Conclusion}

Based on the obtained data, we have identified factors for increasing the educational motivation of students in the process of using electronic educational resources: 
1. The personal significance of the tasks for the student in the course of educational activities. In our opinion, educational tasks should be not only understandable, but also internally accepted.

2. The attractiveness of the tasks and their relationship, obtained in the course of their solution of experience, with its subsequent professional application.

3. Stimulation on the personal result, and not on the assessment of the teacher.

4. The interactive nature of educational interaction.

5. A personal example of a teacher. Students' interest in the subject is due not only to the professional presentation of the teaching material, but also to the personal qualities of the teacher.

The identified factors allow increasing the educational motivation of students in the learning process, which determine scientific significance of the work and can be considered as the scientific novelty of this study. From our point of view, the use of electronic educational resources, which increase the effectiveness of the educational process, has a special didactic potential and practical significance for the formation of pedagogical conditions to increase the educational motivation of students to the learning process.

Teaching accompanied by a course with an electronic educational resource has a very important feature. The electronic educational resource is interactive. Providing interactivity can be considered as one of the pedagogical conditions that allow us to consider the electronic educational recourse as a means of motivation for learning. Interactivity is a powerful tool that, when used correctly, can fuel interest in your course. To increase the level of motivation, it is necessary to create an interactive environment, giving students the opportunity to explore it themselves. This will fuel their natural curiosity and, as a result, draw attention to learning.

The next condition that can contribute to motivation is high quality feedback from teachers due to the interactivity of the electronic educational resource. The student receives an exhaustive review and feedback from a teacher on a number of his actions, so when a student watches educational videos, the student can repeat the teacher's actions at the same time.

Another important condition is the opportunity for students to express their opinion about the electronic resource, which also motivates students to study. Moreover, it should be noted that an electronic educational resource can be used in the likeness of a social network, it allows commenting, and discussing what is manifested in the social nature of interaction.

One more important condition that allows using an electronic educational resource as a motivation for the learning process is that it allows turning a traditional class into an unusual one. This is possible due to the methodological content of the electronic resource (multimedia, videos, animation).

In addition, when a teacher uses his personal electronic educational resource, it becomes possible to really interest the student. One of the most important advantages of electronic educational courses is the possibility of continuous improvement of teaching methods through the use of feedback from students themselves, which ensures a continuous improvement in the quality of education. 
Both teachers and, of course, students themselves can influence the motivation of students. There may be many factors that increase the motivation for learning, but not one of them will "work" if there is no intrinsic motivation or student's acceptance of the activity in which he is involved. The main motive of learning is the internal motive power, when the student realizes for himself the significance of the activity.

The educational institution, in the conditions of modern reality, faces a difficult task - to create such conditions under which the student during his studies could not only master special and general cultural competencies, but also form the qualities of a socially mature person.

The effectiveness of the educational process is directly related to how high the motivation and high incentive to master the future profession. The motivation for learning is a rather complicated and ambiguous process of changing the attitude of an individual, both to a separate subject of study and to all forms of its organization. You can only create the necessary conditions for the student under which he himself will be interested to learn. The creation of such conditions depends on many factors: The influence of the student's social circle, the demands of society, the influence of parents and, of course, the formation of the educational environment. The teacher himself is of great importance as a person and specialist, however, the modern educational trend brings electronic educational resources to the forefront, which requires a student to be highly motivated to do independent work.

As part of our study, we came to the conclusion that external and internal motives are intertwined in the system of educational motives. Internal motives include such as one's own development in the learning process; it is necessary that the student himself wants to do something and do it, since the true source of man is in himself. External motives come from parents, teachers, the group in which the student is studying, i.e. this study is a forced behavior and often meets the internal resistance of the individual. That is why the decisive importance is attached not to the motives of learning - to external pressure, but to the motives of learning - to internal motivating forces. These motives may have unequal power of influence on the nature and results of the educational process. The most pronounced external moments in the motives of study for the sake of material reward and avoidance of failure.

The educational process refers to this complex type of activity, there are many motives for learning, and they can manifest themselves not only separately in each person, but also merge into a single whole, forming complex motivational systems.

From our point of view, e-learning has a special didactic potential for the formation of factors that increase the motivation of students to work independently and the learning process as a whole, which can increase the effectiveness of the students' selftraining process. E-learning acts as an opportunity for the effectiveness of the student learning process. Electronic educational resources have a very important feature. They are interactive, which allows you to get high quality feedback from students in the process of obtaining knowledge. In addition, when a teacher uses a personal electronic course, it becomes possible to really interest the student. 


\section{$5 \quad$ References}

[1] Costa, C., Alvelos, H., Teixeira, L. (2012). The use of Moodle e-learning platform: a study in a Portuguese University. Procedia Technology, 5: 334-343. https://doi.org/10.1016/j.pro tcy.2012.09.037

[2] Danilina, Elena I. (2018). Information Society and Informatization of the Educational Space. European Proceedings of Social and Behavioural Sciences, 46: 622-629

[3] Eljinini, M., Muhsen, Z., Maaita, A., Alnsour, A., Azzam, M., Barhoum, K. (2013). The Utilization of the Moodle E-Learning System in Isra University. Advances in Intelligent Systems and Computing, 220: 75-81. https://doi.org/10.1007/978-3-319-00569-0_10

[4] Freeman,S., Eddy, S.L., McDonough, M., Smith, M.K., Okoroafor, N., Jordt, H., Wenderoth, M.P. (2014).Active learning increases student performances in science, engineering, and mathematics. Proceedings of the National Academy of Sciences, 111: 8410-8415. https://doi.org/10.1073/pnas.1319030111

[5] Khairani, N., Rajagukguk, J., Derlina. (2019). Development of Moodle E-Learning Media in Industrial Revolution 4.0 Era. Advances in Social Science, Education and Humanities Research, 384: 752-758. https://doi.org/10.2991/aisteel-19.2019.172

[6] Lin, H., Doong, J., Lin, X. (2016). The effectiveness of applying moodle E-learning platform on resource classroom students. International Conference on Computer Science, Technology and Application (CSTA2016), 191-198. https://doi.org/10.1142/9789813200 $\underline{449 \_0025}$

[7] Makarova Elena A. Makarova Elena L. (2018) Blending pedagogy and digital technology to transform educational environment. International Journal of Cognitive Research in Science, Engineering and Education, 6: 57-65. https://doi.org/10.5937/ijcrsee1802057m

[8] Medio, C., Limongelli, C., Sciarrone, F., Temperini, M. (2020). MoodleREC: A recommendation system for creating courses using the moodle e-learning platform. Computers in Human Behavior, 104: 106-168. https://doi.org/10.1016/j.chb.2019.106168

[9] Rozanov Alexander S., Chebotareva Anna A., Chebotarev Vladimir E., Rozanova Evgenija I., Siirak, V. (2010). Some experiences of e-learning in the Moodle e-learning environment. Information and Communication Technologies, Society and Human Beings: Theory and Framework. https://doi.org/10.4018/978-1-60960-057-0.ch023

[10] Triyana, I \& Ratmini, Ni \&Mandra, I \& Ruscitadewi, Ni \& Armaeni, Ketut \& Adnyani, Ni. (2019). The Use of Moodle-Based E-Learning in Evaluating Students' Learning. Jurnal Penjaminan Mutu, 5: 165-169. https://doi.org/10.25078/jpm.v5i2.1089

[11] Tsenkova A.K., Borisova T.I., Brnekova D.I., Otuzbirova-Arnaudova A.L., Zafirov H.K., Pavlova M.S. (2018) Digital and language educational environment for the formation of professional competences during the training of pedagogy students. Sciences of Europe, 27: $3-10$

[12] Zashikhina I. Postnikova M. (2019) Social implications of media education in the curriculum of a future teacher. Media education, 59 (4): 608-618

[13] Papadakis, S., Kalogiannakis, M., Sifaki, E., \& Vidakis, N. (2017). Access moodle using smart mobile phones. A case study in a Greek University. In Interactivity, Game Creation, Design, Learning, and Innovation (pp. 376-385). Springer, Cham. https://doi.org/10.1007/ 978-3-319-76908-0 36

[14] Kalogiannakis, M., \& Papadakis, S. (2017). Combining mobile technologies in environmental education: a Greek case study. International Journal of Mobile Learning and Organisation, 11(2), 108-130. https://doi.org/10.1504/ijmlo.2017.10005249 
[15] Bovermann, K., Weidlich, J. \& Bastiaens, T. (2018). Online learning readiness and attitudes towards gaming in gamified online learning - a mixed methods case study. Int $\mathrm{J}$ Educ Technol High Educ 15, 27 https://doi.org/10.1186/s41239-018-0107-0.

[16] Mawardia, D.N., Saputrab, B. (2020) Analysis of Students Motivation, Interest, And Talent in Using Moodle Applications as Distance Media During Pandemic Covid-19. Journal of Xi'a University of Architecture \& Technology, Vol. XII, Issue VII, pp. 759-766.

[17] Aldheleai, Y. M., Tasir, Z., Al-Rahmi, W. M., Al-Sharafi, M. A., \& Mydin, A. (2020). Modeling of students online social presence on social networking sites with academic performance. International Journal of Emerging Technologies in Learning, 15(12), 56-71. https://doi.org/10.3991/ijet.v15i12.12599

[18] An, X., \& Qu, C. (2020). Blending teaching mode for computer courses in the background of emerging engineering education. International Journal of Emerging Technologies in Learning, 15(12), 271-289. https://doi.org/10.3991/ijet.v15i12.14867

[19] Korableva, O., Durand, T., Kalimullina, O., \& Stepanova, I. (2019). Studying user satisfaction with the MOOC platform interfaces using the example of coursera and open education platforms. Paper presented at the ACM International Conference Proceeding Series, 26-30. https://doi.org/10.1145/3322134.3322139

[20] Terentyeva, I., Lunev, A., Kashina, S., Sadrieva, L., Korolyuk, I., \& Pugacheva, N. (2020). The virtual construction site: Knowledge management in virtual environments. International Journal of Emerging Technologies in Learning, 15(13), 81-95. https://doi.org/10. 3991/ijet.v15i13.14655

[21] Kozikoğlu, İ. (2019). Investigating critical thinking in prospective teachers: Metacognitive skills, problem solving skills and academic self-efficacy. Journal of Social Studies Education Research, 10(2), 111-130. Retrieved from www.scopus.com

[22] Morales, D., Ruggiano, C., Carter, C., Pfeifer, K., \& Green, K. (2020). Disrupting to Sustain: Teacher Preparation Through Innovative Teaching and Learning Practices. Journal of Culture and Values in Education, 3(1), 1-20. https://doi.org/10.46303/jcve.03. $\underline{01.1}$

\section{Authors}

Irina A. Talysheva is Associate Professor of the Department of Pedagogy of Kazan Federal University, Elabuga Institute (Branch), Elabuga, Russian Federation. Kazan Federal University, Elabuga Institute of KFU, Kazanskaya Street, 89, 423604, Elabuga, Russia.

Khene R. Pegova is Assistant of the Department of Pedagogy of Kazan Federal University, Elabuga Institute (Branch), Elabuga, Russian Federation. Kazan Federal University, Elabuga Institute of KFU, Kazanskaya Street, 89, 423604, Elabuga, Russia.

Liliya R. Khaliullina is Assistant of the Department of Pedagogy of Kazan Federal University, Elabuga Institute (Branch), Elabuga, Russian Federation. Kazan Federal University, Elabuga Institute of KFU, Kazanskaya Street, 89, 423604, Elabuga, Russia.

Article submitted 2020-07-03. Resubmitted 2020-08-26. Final acceptance 2020-08-31. Final version published as submitted by the authors. 